fused again at Washington, but in May, 1863, President Lincoln sent him an unsolicited commission as captain of volunteers and ordered him to report to the western army under Grant. He joined at Vicksburg and was placed upon General Grant's staff. He was appointed assistant adjutant general and from then on he was General Grant's military secretary. He prepared the papers that were signed by Grant and given to Lee.

He retired with the rank of brevet brigadier general and President Grant made him commissioner of Indian affairs. He had held the high office of sachem of the Six Nations and his Indian name meant "Keeper of the Western Door." He died in 1895 near Buffalo, N. Y.

\title{
EARLY VISIT OF AN EMINENT SCIENTIST
}

When the old dragoon barracks at the Raccoon forks of the Des Moines river had been converted into settlers' stores and temporary residences, the place was visited by one of the most eminent scientists of his time. This was David Dale Owen. He was looking for minerals and things of utility. He rode up the Raccoon valley a little way, then sending his party back, he went on to the Missouri slope, thence down to St. Louis. The valuable coal deposits were too far down for his keen eyes, and the use of the clay and soft stones was not well known. Owen was first and greatest of the geologists to survey Iowa. His work, especially in hasty checking over of the lead deposits in Iowa and Wisconsin, was a marvel of his time.

A splendid new book giving the high lights of his short but intensely interesting life, has been written by Walter Brookfield Hendrickson, and published by the Indiana Historical bureau. Portions of this fine biography were printed in ThE ANNALS OF IowA in July 1942. Little did the man versed in rocks and sands and soils realize that within a century the "Raccoon forks" would be the capital of a great state and the center of a vast industrial activity. The whole story of the man and his work is worth reading. 
Copyright of Annals of Iowa is the property of State of Iowa, by \& through the State Historical Society of Iowa and its content may not be copied or emailed to multiple sites or posted to a listserv without the copyright holder's express written permission. However, users may print, download, or email articles for individual use. 